\title{
The Economic Challenges of Population Aging in Emerging Markets
}

\author{
Michael Herrmann* \\ United Nations Population Fund (UNFPA), New York, USA \\ Email: mic.herrmann@gmail.com
}

Received December 31, 2013; revised January 30, 2014; accepted February 5, 2014

Copyright (c) 2014 Michael Herrmann. This is an open access article distributed under the Creative Commons Attribution License, which permits unrestricted use, distribution, and reproduction in any medium, provided the original work is properly cited. In accordance of the Creative Commons Attribution License all Copyrights (C) 2014 are reserved for SCIRP and the owner of the intellectual property Michael Herrmann. All Copyright (C) 2014 are guarded by law and by SCIRP as a guardian.

\section{ABSTRACT}

Why do studies that examine population aging always come to the same conclusions? Regardless of whether these studies focus on Japan or Germany, Northern Europe or Southern Europe, the developed economies or emerging market economies, they typically suggest that countries will confront a labor shortage which undermines economic growth and that they will confront rising pension and health care costs which call for reduced health care and pension benefits. Are uniform policy recommendations justified because these countries are in fact so similar, or are they rather the result of an undifferentiated and partial analysis? This paper argues that they are the result of a household-focused analysis which fails to take into consideration the very different macroeconomic realities of different countries. From a macroeconomic perspective, this paper examines the broader economic background of emerging markets to understand whether population aging has negative effects on their economic development on the one side, and whether their economic development can cater to an increasing number of old-age dependents on the other.

\section{KEYWORDS}

Population; Aging; National Transfer Accounts; Pensions; Social Protection; Macroeconomics; Structural Change

\section{Introduction}

Why do studies that examine population aging always come to the same conclusions? Regardless of whether these studies focus on Japan or Germany, Northern Europe or Southern Europe, the developed economies are emerging market economies, the studies typically suggest that countries will confront labor shortages which undermines economic growth and that they will confront rising pension and health care costs which call for health care and pension reforms. In accordance, countries are advised to cut or avoid generous health care and pension benefits, shift to fully funded pension systems, and postpone retirement ages. The recommendation that people

*Michael Herrmann is Senior Adviser on Population and Economics with the United Nations Population Fund (UNFPA). The paper benefited from valuable comments by Miguel Sánchez Romero, and discussions with Ingo Pitterle, Detlef Kotte and Andrew Mason. However, the views expressed in this paper are those of the author, and they do not necessarily reflect the views UNFPA. work longer is complemented by studies which suggest that they can. On average, people today live longer and healthier lives and older persons have a higher productivity than in the past [1].

The question is not only whether these policy recommendations are in fact meaningful; the question more fundamentally is why these policy recommendations are always the same. Are these countries so similar that uniform policy recommendations are justified, or are the analyses so undifferentiated that uniform policy recommendations are the natural outcome? The paper argues that many studies which examine population aging focus on economic relationships at the household level and are not paying adequate attention to the economic relationships at the macroeconomic level. A more differentiated analysis of labor markets and macroeconomic relation-

${ }^{1}$ Fernández-Ballesteros et al. [2] underline the important unpaid contributions of older persons to societies; Burtless [3] finds rising labor productivity and labor compensation for older persons. 
ships, which is put forward in this paper, shows that population aging has very different implications and calls for different policy responses in different countries.

The paper's first section highlights population aging trends and projections in developing countries, and the subsequent sections examine its implications. The second section focuses on the implications of population aging for labor markets, and the third section discusses the linkages between higher consumption expenditures and macroeconomics. On the one hand, the paper examines whether countries have the economic resources to provide for a growing number of older persons, esecially for pensions and health care, and on the other hand it explores whether such provisions can have negative implications for economic growth. ${ }^{2}$

\section{Population Aging in the Developing World}

While population aging is most advanced in the developed economies, as measured by the share of older persons in the total population, population aging is happening most rapidly in the developing world. Between now and 2050, the share of older persons in the total population will continue to grow in all regions, but until 2050 the growth of this share will be fastest in developing countries. However considerable differences between developing countries remain. In the developing countries of the Americas and Asia this share will grow faster than in the developed countries of Europe and North America,and in the developing countries in Africa in particular it will grow at a much lower rate. ${ }^{3}$ The differences in this growth rate are mostly attributable to differences in the fertility level. On average, emerging market economies have seen a considerably steeper and faster fall in fertility levels and are therefore more advanced in their demographic transitions than the least developed economies (Table 1).

As declining fertility drives the increase in the relative number of older persons, it is also associated with a relative decrease in the number of younger persons. In the least developed countries the projected decrease in the number of younger persons per working-age adult (young-age dependency ratio) is considerably faster than the increase in the number of older persons per working-age adult (the old-age dependency ratio), leading to a

\footnotetext{
${ }^{2}$ Although population aging most directly affects the demand for pensions and health care, it is useful to see pensions and health care in the context of broader social protection measures. The concept of social protection focuses different risks different people face throughout the course of their life. It entails protection measures for children, working-age adults and the elderly in the area of health, nutrition and income support. For a discussion of social protection measures, see for example Bonilla Garcia and Gruat [4], and ILO [5]; for details on the recommendation concerning national floors of social protection, see ILO [6]. ${ }^{3}$ Population aging is most advanced in East Asia and South America; and the intra-regional differences are greatest for Asia, and Latin America and the Caribbean.
}

fall in the total dependency ratio (the sum of all dependents per working-age adult) over the next forty years or so. However, this window of opportunity, which is provided by a fall in the number of dependents, will eventually close.

This paper focuses on the 20 countries, including mostly developing countries as well as a few developed countries, where population aging will grow fastest over the 2010-2050 period. ${ }^{4}$ In all these countries a rise in the old-age dependency ratio is at least partially offset by a fall in the young-age dependency ratio [7].

In most countries the share of total dependents will increase by less than the share of old-age dependents (Table 2). In accordance, higher spending by households and the public sector on goods and services that are mostly consumed by the elderly (e.g., health) can partially be compensated by lower spending by households and the public sector on goods and services that are mostly consumed by the younger generations (e.g., education) without decreasing spending per person. To evaluate the economic implication of any change in age structures, including the aging of population, it is therefore important to focus on the aggregate implications of all changes.

Furthermore, when evaluating future trends, it is often useful to put them into perspective with past developments. Whereas the total dependency ratio is projected to increase in almost all countries and country groups in the sample by 2050 relative to 2010, the total dependency ratio is actually projected to fall in several of these countries and country groups by 2050 relative to 1950 (Chart 1). In other words, the number of dependents per adult in working-age in 2050 will frequently be smaller than the number of dependents per adult in working age in 1950. The relative number of dependents changes as countries go through their demographic transitions. It increases in the early stages, mostly because of an increase in youngage dependents, it falls in the middle stages, and it increases again in the third stage, mostly because of an increase in old-age dependents. However, dependency ratios do not perpetually increase thereafter. The rise in dependency ratios due to population aging will eventually be followed by a fall in dependency ratios.

An increase in dependency ratios is not a new phenomenon, and countries were able to cope with this phenomenon successfully in the past. However, contrary to the past, when a large and growing share of dependents were children, today a large and growing share of them are older persons. The distinct nature in the composition

\footnotetext{
${ }^{4}$ The list of Top-20 does not include territories, provinces and special administrative regions, nor does this study consider large oil producing and net-oil exporting countries. The increase in the share of older persons is particularly pronounced in Qatar (28), the United Arab Emirates (24), Oman (18), Iran, IR (16), Bahrain (16) and Saudi Arabia (15), but also Brunei Darussalam (19). Because of their economic specificities these countries merit a distinct and focused analysis, and are not covered by this study.
} 
Table 1. Changes in the share of older persons, 2010-2050. (Ranked by share of older persons in total population).

\begin{tabular}{|c|c|c|c|c|c|}
\hline Share of 65+ in 2010 & $\%$ & Share of 65+ in 2050 & $\%$ & Increase in share of $65+$ between $2010-2050$ & $\%$ points \\
\hline World & 7.7 & World & 15.6 & World & 7.9 \\
\hline Regions & & Regions & & Regions & \\
\hline Europe & 16.3 & Europe & 26.9 & Latin America and the Caribbean & 12.5 \\
\hline Northern America & 13.2 & Northern America & 21.8 & Asia & 10.6 \\
\hline Oceania & 10.7 & Latin America and the Caribbean & 19.3 & Europe & 10.5 \\
\hline Asia & 6.8 & Oceania & 17.9 & Northern America & 8.6 \\
\hline Latin America and the Caribbean & 6.8 & Asia & 17.4 & Oceania & 7.2 \\
\hline Africa & 3.4 & Africa & 5.9 & Africa & 2.4 \\
\hline Development status & & Development status & & Development status & \\
\hline Developed countries & 16.1 & Developed countries & 25.8 & Other developing countries & 9.7 \\
\hline Other developing countries & 6.2 & Other developing countries & 16.0 & Developed countries & 9.7 \\
\hline Least developed countries & 3.5 & Least developed countries & 6.9 & Least developed countries & 3.4 \\
\hline Top-20 countries & & Top-20 countries & & Top-20 countries & \\
\hline Japan & 23.0 & Japan & 36.5 & Republic of Korea & 23.8 \\
\hline Germany & 20.8 & Republic of Korea & 34.9 & Cuba & 21.9 \\
\hline Italy & 20.3 & Spain & 34.5 & Thailand & 21.5 \\
\hline Greece & 19.0 & Portugal & 34.4 & Singapore & 19.9 \\
\hline Latvia & 18.4 & Cuba & 34.4 & Spain & 17.4 \\
\hline Bulgaria & 18.3 & Italy & 33.0 & Lebanon & 17.2 \\
\hline Sweden & 18.2 & Germany & 32.7 & Costa Rica & 16.6 \\
\hline Portugal & 18.0 & Greece & 32.1 & Viet Nam & 16.5 \\
\hline Austria & 17.8 & Slovenia & 30.4 & Portugal & 16.4 \\
\hline Croatia & 17.5 & Thailand & 30.4 & Tunisia & 16.0 \\
\hline Estonia & 17.5 & Malta & 29.3 & Brazil & 15.6 \\
\hline Belgium & 17.2 & Croatia & 29.2 & China & 15.6 \\
\hline Finland & 17.1 & Qatar & 29.1 & Poland & 15.6 \\
\hline Spain & 17.1 & Poland & 29.1 & Chile & 15.4 \\
\hline Switzerland & 16.9 & Singapore & 28.9 & Slovakia & 15.4 \\
\hline France & 16.8 & Bulgaria & 28.6 & Macedonia, TFYR & 15.0 \\
\hline Hungary & 16.7 & Serbia & 28.4 & Serbia & 14.6 \\
\hline Denmark & 16.7 & Romania & 28.2 & Cyprus & 14.5 \\
\hline Slovenia & 16.7 & Slovakia & 27.7 & Mexico & 14.2 \\
\hline United Kingdom & 16.6 & Austria & 27.6 & Turkey & 14.1 \\
\hline
\end{tabular}

Source: UN, World Population Prospects 2012 Revision, online 22 July 2013. Note: Based on medium variant of population projections. For the purpose of this study, older persons are defined as $65+$.

of dependents has distinct implications for the economy and policy making. Whereas the challenge during the early stages of the demographic transition is an essentially unlimited supply of labor ${ }^{5}$, it is often argued that the challenge during the later stages of the demographic transition is a shortage of labor. Both developments can affect the returns to, and investments in, the factors of production, and therefore have far-reaching implications for income distribution and poverty, and the nature of economic development. The implications of an aging

${ }^{5}$ The economic implications of an unlimited supply of labor, are extensively discussed in the literature on the dual economy and the dual-dual economy, including the works of Lewis [8], Fei and Ranis [9] and Herrmann and Khan [10]. population for labor markets and economic development, as well as the financing of social protection, including health and pensions, are examined in the subsequent sections.

\section{The Linkages to Labor Markets}

To understand how changes in dependency ratios affect economic developments, it is important to make a distinction between demographic and economic dependency ratios. Whereas the demographic dependency ratios focus on the number of people in working age relative to those outside, the economic dependency ratio would focus on the number of people who hold gainful employment rela- 
Table 2. Change in dependency ratios, 1950-2050. (Percentage points, ranked by change in old-age dependency).

\begin{tabular}{|c|c|c|c|c|c|c|c|c|c|}
\hline & \multirow{2}{*}{\multicolumn{3}{|c|}{$\begin{array}{c}\text { Old-age dependency ratio } \\
\text { (ratio of population aged } 65+\text { per } \\
100 \text { population } 15-64 \text { ) }\end{array}$}} & \multirow{2}{*}{\multicolumn{3}{|c|}{$\begin{array}{c}\text { Child dependency ratio } \\
\text { (ratio of population aged } 0 \text { - } 14 \\
\text { per } 100 \text { population } 15 \text { - 64) }\end{array}$}} & \multirow{2}{*}{\multicolumn{3}{|c|}{$\begin{array}{c}\text { Total dependency ratio } \\
\text { (ratio of population aged } 0 \text { - } 14 \\
\text { per } 100 \text { population } 15-64 \text { ) }\end{array}$}} \\
\hline & & & & & & & & & \\
\hline & 2010 & 2050 & $2010-2050$ & 2010 & 2050 & $2010-2050$ & 2010 & 2050 & $2010-2050$ \\
\hline World & 11.7 & 24.7 & 13.0 & 40.5 & 33.8 & -6.8 & 52.2 & 58.5 & 6.2 \\
\hline \multicolumn{10}{|l|}{ Regions } \\
\hline Europe & 23.9 & 46.6 & 22.6 & 22.6 & 26.6 & 4.1 & 46.5 & 73.2 & 26.7 \\
\hline Latin America and the Caribbean & 10.4 & 30.5 & 20.1 & 43.2 & 27.8 & -15.4 & 53.6 & 58.3 & 4.7 \\
\hline Asia & 10.1 & 27.0 & 16.9 & 37.6 & 27.7 & -9.9 & 47.6 & 54.7 & 7.1 \\
\hline Northern America & 19.6 & 36.2 & 16.6 & 29.0 & 29.8 & 0.9 & 48.5 & 66.0 & 17.5 \\
\hline Oceania & 16.4 & 29.0 & 12.6 & 36.7 & 33.1 & -3.7 & 53.1 & 62.0 & 8.9 \\
\hline Africa & 6.2 & 9.5 & 3.3 & 74.2 & 52.0 & -22.2 & 80.4 & 61.5 & -18.9 \\
\hline \multicolumn{10}{|l|}{ Development status } \\
\hline Developed countries & 23.8 & 44.4 & 20.6 & 24.3 & 27.7 & 3.4 & 48.1 & 72.1 & 24.0 \\
\hline Other developing countries & 9.3 & 24.9 & 15.6 & 40.0 & 31.0 & -9.0 & 49.3 & 55.9 & 6.6 \\
\hline Least developed countries & 6.2 & 10.9 & 4.7 & 73.4 & 47.8 & -25.6 & 79.6 & 58.6 & -20.9 \\
\hline \multicolumn{10}{|l|}{ Top-20 countries } \\
\hline Republic of Korea & 15.2 & 65.7 & 50.4 & 22.3 & 22.6 & 0.2 & 37.6 & 88.2 & 50.6 \\
\hline Cuba & 17.7 & 63.2 & 45.5 & 24.6 & 20.8 & -3.9 & 42.3 & 84.0 & 41.7 \\
\hline Spain & 25.2 & 66.9 & 41.7 & 22.0 & 26.9 & 4.9 & 47.1 & 93.8 & 46.6 \\
\hline Thailand & 12.4 & 53.1 & 40.8 & 26.9 & 21.8 & -5.1 & 39.3 & 75.0 & 35.7 \\
\hline Portugal & 27.0 & 64.3 & 37.3 & 22.7 & 22.5 & -0.2 & 49.6 & 86.7 & 37.1 \\
\hline Singapore & 12.2 & 48.7 & 36.5 & 23.5 & 19.9 & -3.7 & 35.8 & 68.5 & 32.8 \\
\hline Poland & 18.9 & 51.0 & 32.1 & 21.0 & 24.3 & 3.3 & 39.9 & 75.3 & 35.4 \\
\hline Slovakia & 17.0 & 47.5 & 30.5 & 20.8 & 24.0 & 3.2 & 37.8 & 71.5 & 33.7 \\
\hline Lebanon & 12.5 & 42.1 & 29.7 & 34.9 & 22.0 & -13.0 & 47.4 & 64.1 & 16.7 \\
\hline Serbia & 19.8 & 48.0 & 28.2 & 24.3 & 21.4 & -2.9 & 44.1 & 69.5 & 25.3 \\
\hline Macedonia, TFYR & 16.4 & 44.4 & 28.0 & 24.6 & 22.1 & -2.5 & 41.0 & 66.5 & 25.5 \\
\hline Tunisia & 10.0 & 37.7 & 27.7 & 33.8 & 26.7 & -7.1 & 43.8 & 64.3 & 20.6 \\
\hline China & 11.4 & 39.0 & 27.6 & 24.7 & 24.0 & -0.6 & 36.0 & 63.0 & 27.0 \\
\hline Costa Rica & 9.5 & 37.1 & 27.6 & 36.3 & 23.8 & -12.5 & 45.8 & 60.9 & 15.1 \\
\hline Viet Nam & 9.3 & 36.9 & 27.6 & 33.6 & 23.3 & -10.3 & 42.9 & 60.2 & 17.3 \\
\hline Chile & 13.4 & 40.9 & 27.6 & 32.2 & 25.6 & -6.7 & 45.6 & 66.5 & 20.9 \\
\hline Cyprus & 16.4 & 43.3 & 26.9 & 25.1 & 23.0 & -2.1 & 41.5 & 66.3 & 24.8 \\
\hline Brazil & 10.2 & 36.2 & 25.9 & 37.7 & 24.5 & -13.2 & 47.9 & 60.7 & 12.7 \\
\hline Turkey & 10.6 & 34.0 & 23.3 & 40.3 & 26.3 & -14.0 & 50.9 & 60.3 & 9.4 \\
\hline Mexico & 9.4 & 32.0 & 22.6 & 47.0 & 26.3 & -20.6 & 56.3 & 58.3 & 2.0 \\
\hline
\end{tabular}

Source and note: See Table 1.

tive to all others. Although the two are often hastily equated, they are not the same. The number of people in working age is very different from the number of people that hold gainful employment. Furthermore, the focus on the number of people who are working - relative to all those who are not and are therefore economically dependent-will need to be complemented by a focus on the productivity of the people who are working. A large number of workers can support only a very small number of dependents if they have a low labor productivity and low labor income, which is the case in the world's least developed countries, whereas a small number of workers can support a large number of dependents if they have a high labor productivity and income. ${ }^{6}$

It is often suggested that population aging will lead to

\footnotetext{
${ }^{6}$ In least developed countries a large share of the working-age population is engaged in economic activities from young to old ages but in these countries the majority of the active labor force suffers from low labor productivity. Therefore about 60 per cent of the people who are working continue to live with dollar 1.25 per person and day adjusted for purchasing power parities. The low levels of labor productivity and income make it very difficult for the population of the least developed countries to support a large and growing number of dependents in the coming years. For a discussion of population dynamics, labor market challenges and poverty in the least developed countries, see UNFPA [11], as well as ILO [12].
} 


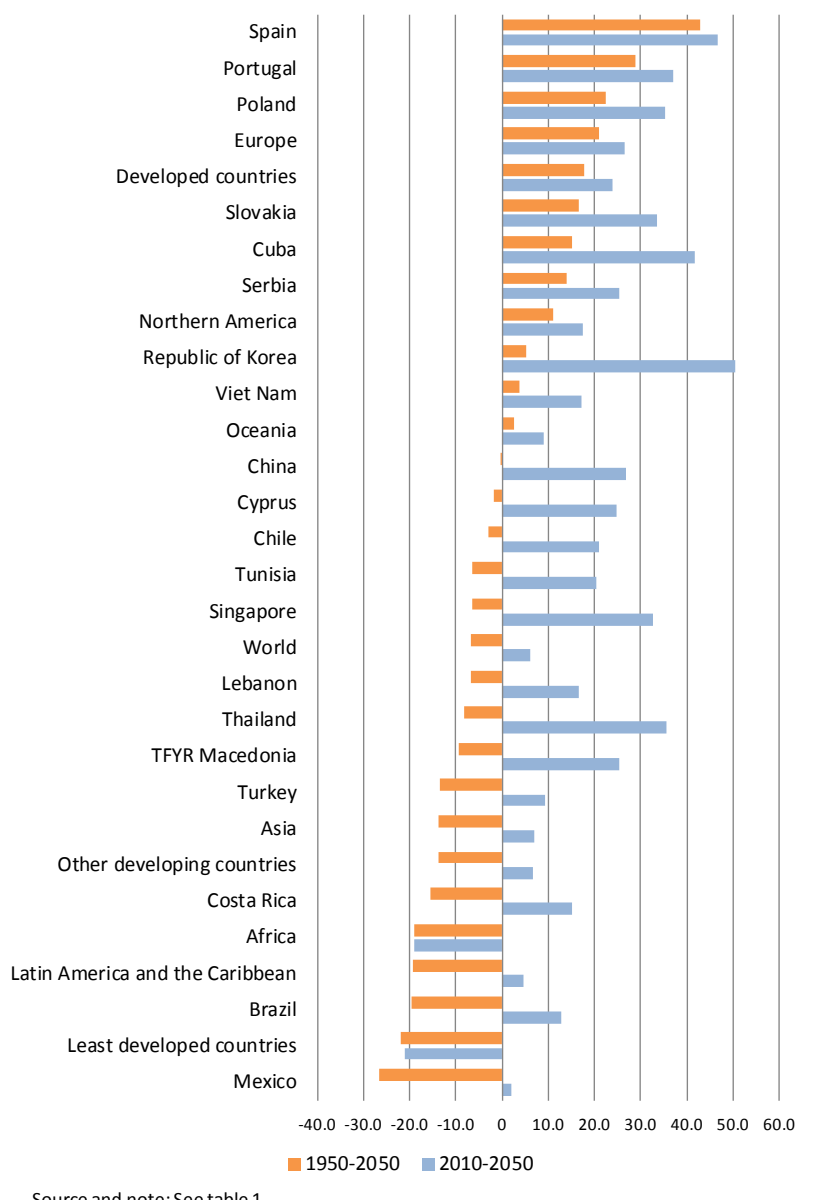

Source and note: See table 1 .

Chart 1. Change in the total dependency ratio of selected regions and countries, 1950-2050 and 2010-2050.

a labor shortage, and that the labor shortage will undermine economic development. This is a hasty conclusion however. The aging of a population does not necessarily mean a decline in the working-age population; a decline in the working-age population does not necessarily lead to a decline in the labor force; a decline in the labor force does not necessarily lead to a decline in employment; and even a decline in employment does not necessarily imply a labor shortage. In almost all countries a considerable share of the working-age population is not employed and not actively looking for a job (i.e., is part of the inactive labor force), and in some countries a large share of the working-age population that is looking for a job is often unemployed. In the developing countries that provide no or little unemployment benefits, underemployment is typically a considerable challenge as well. In this sample of countries, on average 37 per cent of the working-age population were out of work (Chart 2). The only meaningful measure of a labor shortage, which is distinct from a skill shortage, is a persistently low and falling unemployment rate. But the changes in the unemployment rate also greatly depend on changes in labor force participation rates.

While the majority of countries are witnessing an increase in older persons relative to the working-age population, hardly any country has so far seen a decline in the working-age population in absolute terms. The working-age population continues to grow for decades to come in the developing countries in this sample, and between 1990 and 2012 the working-age population declined in only three of the developed countries of the world. The decline was most pronounced in Estonia, where it shrunk by 0.7 per cent per annum, followed by Japan where it declined by 0.3 percent per annum and the by Germany where it declined by 0.2 percent per annum, on average. Furthermore, amongst these countries, the fall in the working-age population has been associated with a fall in the labor force solely in Estonia. However, this decline was partially offset by an increase in the labor force participation rate, and this increase was largely due to a more active engagement of women (Chart 3).

Women typically make up an over-proportionate share of the inactive labor force. The participation of women in the labor markets is often limited because of their engagement in and around the household. They are typically the primary care takers of children, the elderly and the sick, and in the poorest communities they are also responsible for the collection of fire wood and water, and in remote areas they are often responsible for hauling produce to the market. In accordance, access to care facilities for toddlers, children and the elderly [13]; improved access to water, sanitation and electricity; as and the development of transport networks could create the basis for a more active participation of women in the labor market. However, in many cases female labor force participation also remains constrained by laws, cultures, traditions and prejudices, and where women receive lower pay for the same work as men, it is also discouraged by an unfavorable incentive structures.

Contrary to developed countries which have relatively high unemployment, particular following the global financial and economic crisis, unemployment is rather low in most developing countries. While low levels of unemployment increase the chance of skill shortageswhere companies are not easily able to meet their needs for certain skill sets simply because people with such skill sets are not readily available - even low levels of unemployment do not need to result in an acute and general labor shortage. The difference between the two is important, as the policy responses to either would vary. To address a skill shortage companies should be allowed to selectively hire retirees or foreign professionals; to address a general labor shortage countries could decide to postpone the retirement age or increase immigration levels. Furthermore, a large inactive labor force represents a great untapped potential. Most countries, includ- 


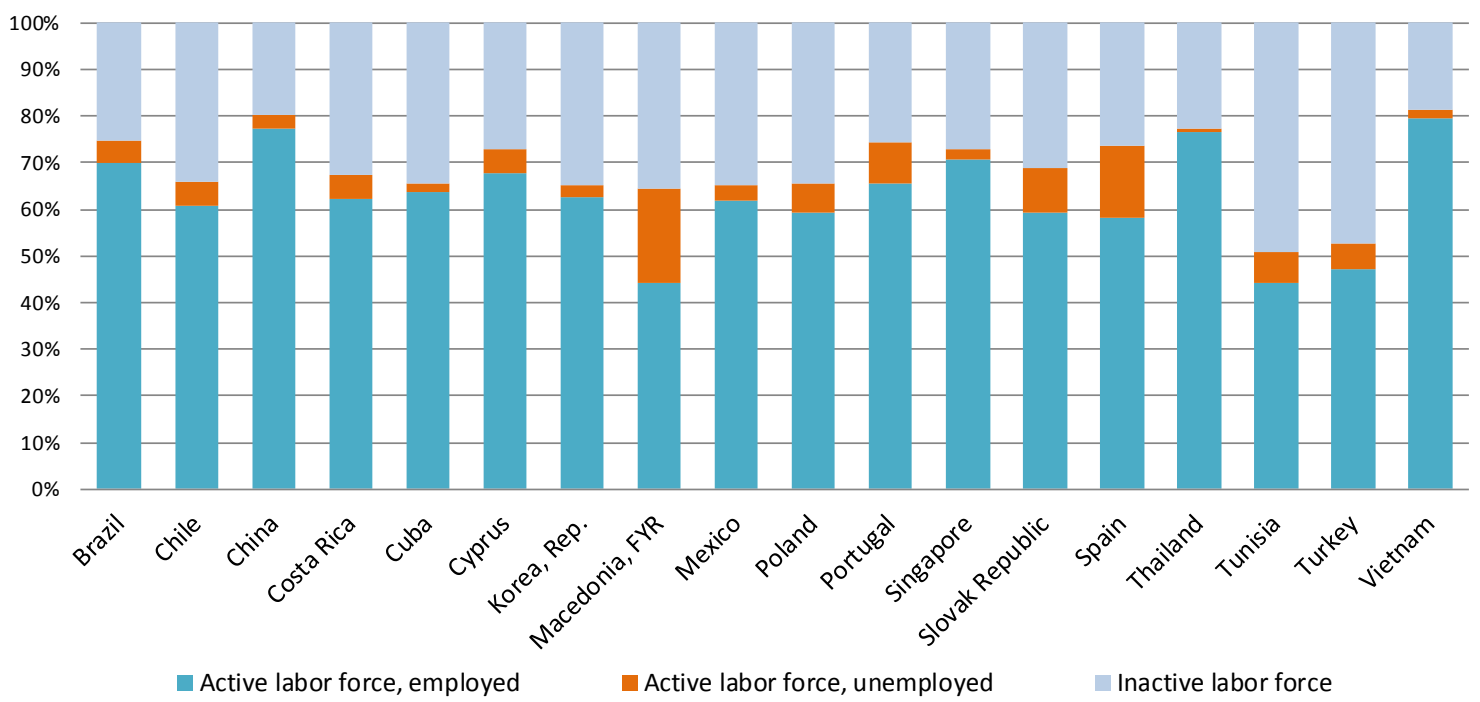

Source: Estimates, based on World Bank, WDI 2013, and ILO, KILM 2013, online 14 July 2013.

Note: Because of insufficient data, Lebanon and Serbia are not included.

Chart 2. Labor force and employment in selected countries and regions, average 2010-2011 (Per cent of working-age population, 15 - 64 years).

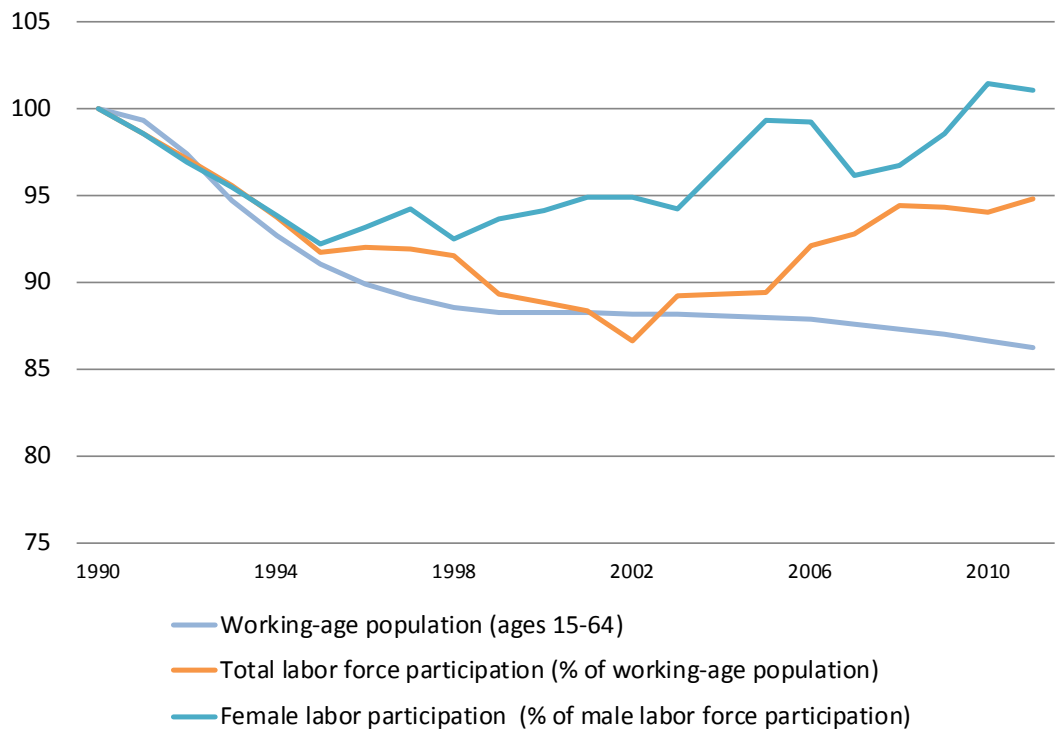

Source: Estimates based on World Bank, WDI 2013 and ILO, KILM 2013 online, 27 July 2013.

Chart 3. Trends in working-age population and labor force participation in Estonia, 1990-2011 (Index, 1990=100).

ing those in this sample, could do much more to increase labor force participation rates.Finally, it is hasty to associate changes in the number of people who are working with changes in the growth of economies. Much more important than prospective changes in the size of the labor force are changes in labor productivity.

Chart 4 summarizes the trends that are detailed in Table 3. In the countries in this sample, the considerable increase in old-age dependencies between 2000-2010 was not associated with a decline in the working-age population, by contrast. In all countries with the exception of Serbia the working-age population continued to increase, and in all countries with the exception of Portugal, Turkey and Vietnam the labor force increased even faster. Furthermore, all countries with the exception of Mexico saw a positive development in their labor productivity. In a few countries the growth in labor productivity was higher than the growth in old-age dependents, and in almost all countries the growth in labor productivity exceeded that of the total number of dependents. The 


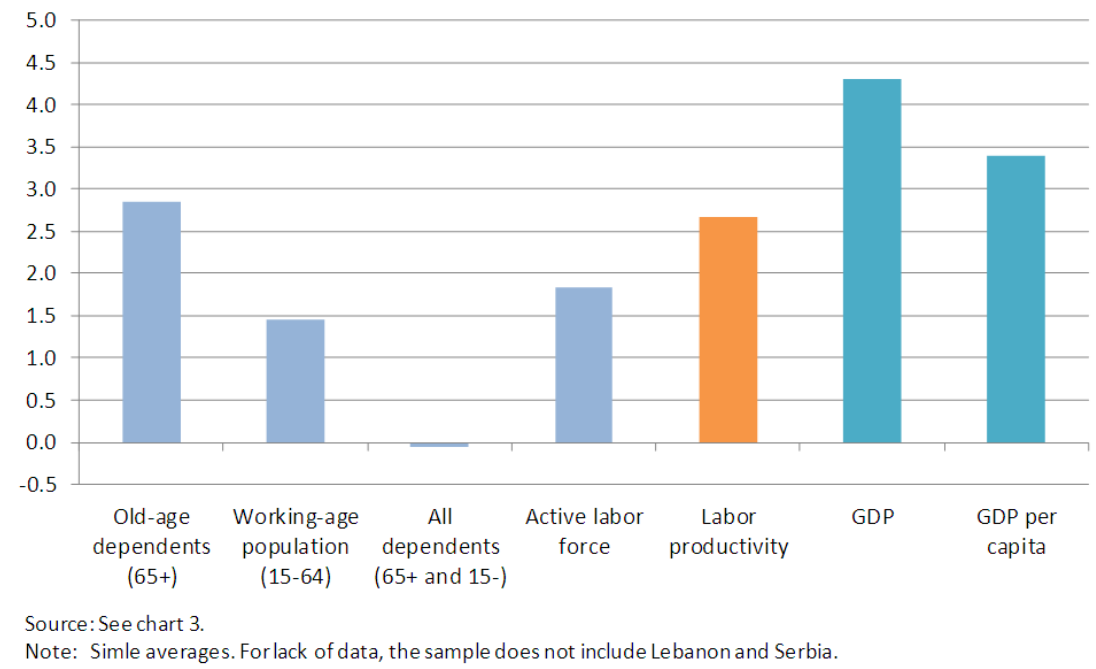

Chart 4. Change in dependents, working-age population and labor force in selected countries, 2000-2010 (Annual average in per cent).

Table 3. Change in dependents, working-age population and labor force in selected countries, 2000-2010 (Annual average in percent).

\begin{tabular}{|c|c|c|c|c|c|c|c|}
\hline & $\begin{array}{c}\text { Old-age } \\
\text { dependents } \\
(65+)\end{array}$ & $\begin{array}{l}\text { All dependents } \\
\text { (65+ and 15-) }\end{array}$ & $\begin{array}{l}\text { Working-age } \\
\text { population } \\
(15-64)\end{array}$ & $\begin{array}{c}\text { Active labor } \\
\text { force }\end{array}$ & $\begin{array}{c}\text { Labor } \\
\text { productivity }\end{array}$ & Real GDP & $\begin{array}{l}\text { Real GDP } \\
\text { per capita }\end{array}$ \\
\hline & (a) & (b) & (c) & (d) & (e) & & \\
\hline Brazil & 3.7 & 0.3 & 1.6 & 2.4 & 1.4 & 3.7 & 2.5 \\
\hline Chile & 3.7 & -0.1 & 1.7 & 3.1 & 0.9 & 3.9 & 2.8 \\
\hline China & 2.7 & -1.4 & 1.5 & 1.1 & 11.2 & 10.3 & 9.6 \\
\hline Costa Rica & 3.8 & 0.1 & 2.7 & 3.2 & 1.4 & 4.2 & 2.3 \\
\hline Cuba & 2.6 & -0.4 & 0.4 & 1.5 & 3.9 & 5.3 & 5.1 \\
\hline Cyprus & 3.0 & 0.5 & 2.2 & 2.8 & 0.2 & 3.1 & 1.3 \\
\hline Korea, rep & 5.2 & 0.2 & 0.7 & 1.1 & 3.3 & 4.6 & 4.0 \\
\hline Lebanon & 5.3 & 2.1 & 3.8 &.. &.. & 4.8 & 1.9 \\
\hline Macedonia & 1.9 & -0.8 & 0.7 & 1.5 & 1.3 & 2.8 & 2.5 \\
\hline Mexico & 3.5 & 0.5 & 1.8 & 1.9 & -0.1 & 2.3 & 0.9 \\
\hline Poland & 1.0 & -1.0 & 0.4 & 1.3 & 2.8 & 3.9 & 4.1 \\
\hline Portugal & 1.4 & 0.5 & 0.2 & 0.0 & 0.8 & 1.0 & 0.6 \\
\hline Serbia & 0.0 & -1.4 & -0.3 & .. & .. & 3.9 & 4.2 \\
\hline Singapore & 5.2 & 1.8 & 3.2 & 3.4 & 2.5 & 6.1 & 3.7 \\
\hline Slovakia & 0.9 & -1.1 & 0.6 & 1.0 & 4.0 & 4.5 & 4.5 \\
\hline Spain & 1.6 & 1.5 & 1.4 & 1.9 & 0.3 & 2.3 & 1.0 \\
\hline Thailand & 4.0 & -0.2 & 1.0 & 1.3 & 3.2 & 4.4 & 3.7 \\
\hline Tunisia & 2.6 & -0.6 & 2.0 & 2.2 & 2.4 & 4.5 & 3.5 \\
\hline Turkey & 3.2 & 0.5 & 1.9 & 1.3 & 2.8 & 4.3 & 2.9 \\
\hline Viet Nam & 1.2 & -1.3 & 2.3 & 2.1 & 5.7 & 7.2 & 6.0 \\
\hline
\end{tabular}

Source and note: See Chart 4

exceptions were Mexico, where labor productivity growth was negative, and Cyprus and Spain where labor productivity growth was low. However, a weak growth in labor productivity can to an extend be compensated by an in- crease in labor force participation.

It is the combination of both, labor productivity and labor force participation, that will determine the level of economic output. In most countries in the sample, eco- 
nomic output and economic output per capita grew faster than the total number of dependents. In this sample, Cyprus, Lebanon, Mexico, Portugal and Spain are the exception. If this trend persists, they will have fewer resources to cater for a growing number of dependents. In this case, redistributive measures to the benefits of dependents will come at the cost of other cohorts. They will directly or indirectly decrease pay checks and/ or profits, or they will imply rising debt.

However, while weak economic development can challenge the ability of countries to provide comprehensive social protection measures for dependents, there is no indication that a growing number of old-age dependents are causing a weak economic development. To date, population aging was rarely been associated with a shirking in the working-age population or labor force, and where it was it was partially offset by an increase in the labor force participation. There is no indication that countries have a labor shortage due to population aging, although some may confront skill shortages. However, unlike labor shortages across the board-which could be addressed through a more active engagement of the inactive labor force, the postponement of the retirement age, and/or an increase in immigration-skills shortage requires more targeted interventions. Finally, more important than the number of people who are working for economic development and growth is the productivity of those working.

\section{The Financing of Health Care, Pensions and Other Social Protection Measures}

National transfer accounts are a useful starting point in the examination of the economic implications of population aging [14]. They show the current distribution of consumption and labor income by age groups (Chart 5), and on this basis allow for an examination of how the distribution of consumption and labor income may change with age structures.

At a young age, individuals typically have no or low labor income but relatively high consumption expenditures, which are largely related to education, and in old age they will again have low or now labor income and relatively high consumption expenditures, which are mostly related to health care. In both cases consumption expenditures exceed labor income, and only in working-age years does labor income exceed consumption expenditures. Through the course of their lives, most people consume more than they earn resulting in the so-called life-cycle deficit. Theoretically, it would be possible to calculate the balance between consumption and labor income for each age group but practically this is not meaningful. Without making children or the elderly work, children or the elderly will always consume more than they earn. It would not be meaningful to ex- pect that each age group can cover their share in consumption expenditures through labor income, and indeed it is not even meaningful to expect that people over their life course cover the total final consumption of countries. In all countries consumption expenditures arefinanced through different sources, and there is no country where labor income alone is sufficient to cover total consumption expenditures. Whether countries have a lifecycle deficit is not necessarily an economic problem, and how they finance it is largely a political and social question. ${ }^{7}$

While the largest share of consumption expenditures is typically financed from returns to labor, a share of consumption expenditures is also financed from the returns to capital. This is particularly important as the labor share in income has declined in most countries, including most of the countries that are included in this study. Chart 6 shows the wage share in GDP for the countries for which data were available over the 1995-2011 period. The decline in this share was strongest Turkey, Poland and the Republic of Korea; the exceptions to the general trend are Singapore and Slovakia. Furthermore, while it is arguably more sustainable to finance current consumption expenditures through a current stream of income, in many cases consumption expenditure are financed through the accumulation of debt or the sale of assets. Either can make economic sense, if it contributes to productive investment and higher output, which increases the stream of income.

National transfer accounts analysis-and the distribution shown in Chart 5-suggests how the life- cycle deficit will change with age structures. All else equal, an increase in the working-age population should result in an increase in labor income relative to consumption expenditures, whereas an increase in young or old-age dependents should result in an increase in consumption expenditures relative to labor income. The former would result in an increase in saving-which many associate with a window of opportunity for countries to realize the demographic bonus - and the latter would lead to a decrease in saving. ${ }^{8}$

Although saving will eventually equal investment, it is important to emphasize that this is but an accounting identity which does not necessarily suggest that saving will cause higher investment. Different macroeconomic theories offer diverging perspectives on how changes in saving will affect economic development. Contrary to

${ }^{7}$ In all countries for which data was available in the 1980s (16), the 1990s (79), and the 2000 (91) has a life-cycle deficit, where the compensation of employees exceeded the consumption expenditures of the country. Estimates are based on United Nations Data, 3 August 2013 online.

${ }^{8}$ For example, Bloom, Canning and Fink [15] see higher saving as important for economic development; and the McKinsey Global Institute [16], as well as Elmendorf and Sheiner [17] see it as an important response to population aging. By contrast, for a critical discussion of this perspective, see for example Dullien [18] and UNCTAD [19]. 


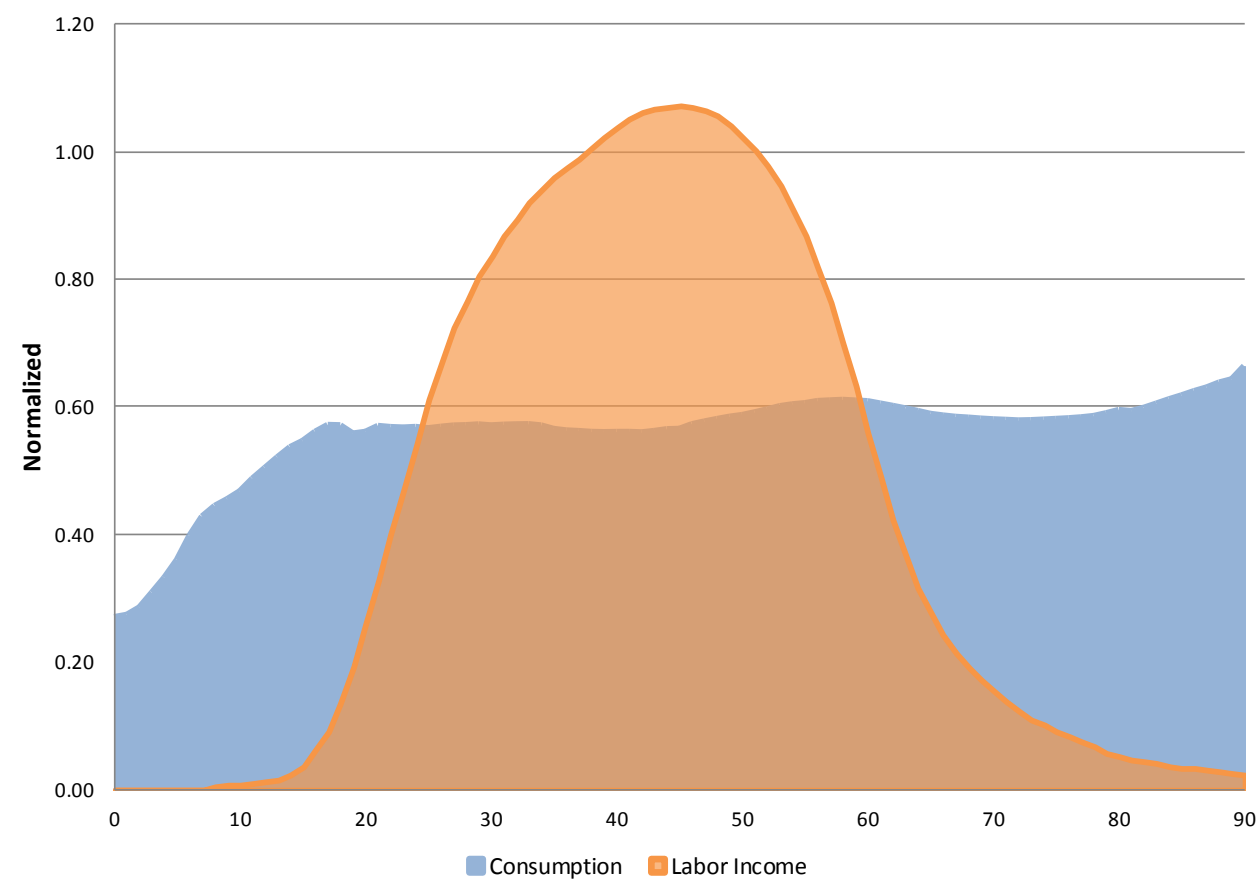

Source: R. Lee and A. Mason (2010).

Chart 5. Average life-cycle deficit of 23 countries, latest years.

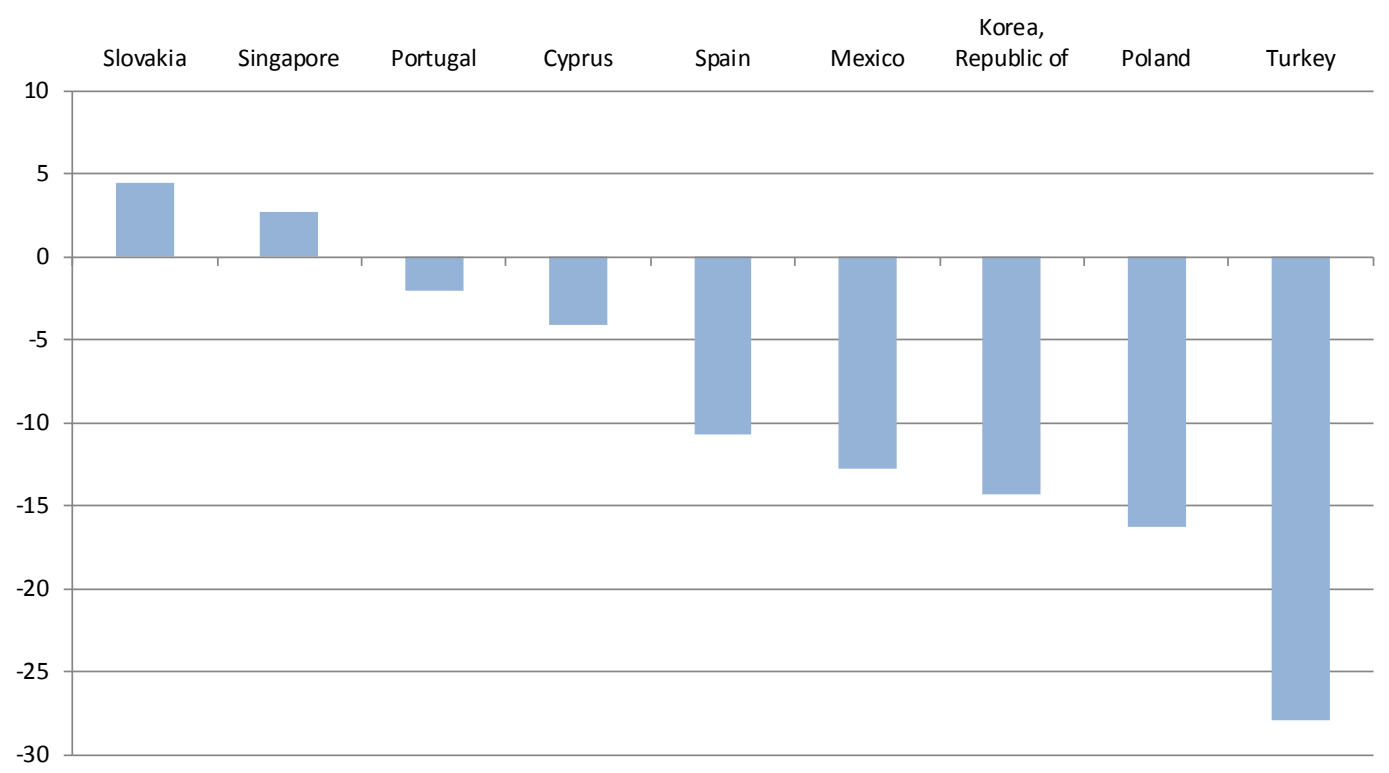

Source: ILO Global Wage Database, online, 1 August 2013.

Note: For lack of data, other countries in the sample were not included.

Chart 6. Change in the wage share in GDP, selected countries 1995-2011. (Percent).

supply-siders (neo-classical economists), who assume that saving will lead to lower interest rates which stimulate investment, demand-siders (Keynesian economists) would expect that higher saving result in higher inventories which discourage investment. Ultimately, it is the macroeconomic theories that analysts adhere by-not the distribution represented by national transfer accounts, or the expected changes in these distributions - that will determine their recommendations to policy makers. The observed or projected changes in national transfer accounts, or national accounts for that matter, do not suggest any particular change in policies.

If it is assumed that higher consumption expenditures will negatively affect investment, countries may be en- 
couraged to decrease consumption expenditures on health, and if it is assumed that higher saving would positively influence investment, countries may be encouraged to shift from unfunded to funded pension systems. Contrary to unfunded pension systems which favors consumption over saving (contributions are used to finance the consumption of pensioners today), the funded system favors saving over consumption (contributions are set aside to finance the consumption of pensioners in the future). However, while individuals can save for the future, an economy cannot. The only way for an economy to transfer wealth into the future is by ensuring productive investment of its resources in the present. To this end, countries should take all necessary measures to discourage financial speculation and ensure that saving are in fact channeled into the production of goods and services. The ambition to promote productive investment, full employment and economic growth, rather than higher saving as such, should guide policy making.

Furthermore, from a macroeconomic perspective it is not meaningful to view consumption in opposition to labor income, as one is but the flipside of the other. For example, an increase of consumption expenditures on health care can provide employment and income to a large number of professionals in the health care sector. In other words, to lower consumption expenditures of the people outside working age (i.e., the young and old-age dependents) countries would lower the labor income of people inside the working age. Efforts to reduce the life-cycle deficit by curbing consumption would therefore backfire, as it would lead lower labor income which would increase the life-cycle deficit in turn. This negative feedback loop can be avoided only in one of two ways. One, countries can try to counter-balance lower consumption expenditures through an increase in debt. However, while a greater saving effort may result in higher debt, higher debt can hardly be its intended outcome. Tow, countries can try to compensate for lower domestic consumption through a greater reliance on external consumption. But this strategy does not work for all countries at all times, as not all countries can simultaneously run current account surpluses. ${ }^{9}$

Growing economic output per capita enlarges the options of policy makers. It enables them to allocate more resources to health care, pensions and other social protection measures even without reducing the resources

\footnotetext{
${ }^{9}$ While most countries have a strategy to boost exports, this is easier said than done. Not only is export performance depended on exchange rate and labor market policies, or trade and investment policies - which are often constrained by trade and investment agreements - but export performance is also dependent on structural factors, including infrastructure, supply capacities, production capacities, and tacit knowledge and know-how. While appropriate macroeconomic policies are needed to boost export performance, the experience of diverse countries at different stages of development [20] shows that the right macroeconomic policies alone do not provide a quick fix to fundamental structural weaknesses.
}

allocated to other areas. Whether policy makers will do so is less a question of economic capacity; it rather is a question of their macroeconomic understanding and societal consensus. For example, many countries on the European continent would favor a higher level of social protection measures, including health care and pensions, and accept a greater element of solidarity than United States of America. On the one side of the spectrum, countries may decide to provide public systems of social protection, which necessitate a more far-reaching redistribution of economic resources through the public sector, and on the other side of the spectrum they may favor private systems of insurance, and minimize the retribution of economic resources through the public channels. ${ }^{10}$

While a country's choice of a social system is circumscribed by the societal consensus and political feasibilities, these choices have important economic implications. The decisions of developed countries to reform health care and pension systems, which benefited from contributions by employers and the public sector, and to introduce instead health care and pension systems, which rely more strongly on the contributions of each individual, effectively reduce the element of solidarity. As a result, such policy reforms in response to population aging further exacerbate the significant rise in economic inequalities during the past decades. Developing countries that are now confronted with an aging population will need to decide whether they want to follow this lead. They do not have to.

In response to population aging, developed countries have often thrown out the baby with the bathwater. There is no doubt that a change in age structures - an increase in youth populations like the increase in the old-age population --- will require responses by policy makers. However, the necessary reform of health care and pension systems should not be hastily misinterpreted as the failure of health care and pension systems. A sustainable system is not the one that will resist changes - this would be a misguided hope and endeavor in world where the only constant is change - but rather the one that can adapt to changes. Countries can decide to reduce or minimize the benefits of health care and pension systems in order to circumvent higher contributions by workers and/ or employers, or they can decide to increase the contributions to health care and pension systems to avoid lowering benefits to the elderly. In most cases, countries have sought to implement a combination of both. Whereas a

\footnotetext{
${ }^{10}$ Although redistribution can create negative incentives for capital and labor, most countries have considerable leeway in designing redistributive policies. Today the inequality between capital and labor, and the income inequality between the richest and the poorest is greater than ever. The rise in these inequalities has also further exacerbated the large inequalities in wealth distribution. For an examination of the causes of rising inequalities, see for example Herrmann [21], IMF [22], ILO [23] and IMF and ILO [24], and for trends in unit labor costs, wages and income inequality, see UNCTAD [25] and ILO [26].
} 
lowering of benefits will inevitably make the dependents worse off, an increase in contributions will not necessarily make labor and/or capital worse off. The net effect on labor and capital critically depends on productivity and the returns to labor and capital. Assuming that labor productivity and labor income grows at 2 per cent per annum in real terms, labor can increase their social security contributions by up to 2 per cent per annum without being worse off. If rising labor productivity does not translate into higher income of workers, it will translate into higher returns to capital. A higher share of social security contributions could therefore be covered by employers.

To complement social protection systems, several developing countries are experimenting with micro-finance and insurance schemes. Such schemes however cannot insure risks that are almost certain to happen, such as an income shortfall of a poor person. To provide protection for people who do not have regular job or income, requires the pooling of risks. Risk pooling across the population represents an element of solidarity that is the defining feature of social protection systems. In some cases, private insurance can reach the scale to provide social protection, but in most cases it is the public sector that will need to assume this role. Like private insurance, public protection systems provide benefits on the basis of needs, but unlike most private insurance, public protection systems also define contributions on the basis of economic ability.

Social protection is not a luxury but a necessity for social and economic development. Social protection measures are countercyclical in nature, as they discourage a contraction in consumption, and therefore they act as automatic stabilizers during economic downturns. But social protection measures, which are based on a fair distribution of contributions and benefits, also help to reduce inequalities and contribute to social cohesion. Furthermore, national transfer accounts, like national accounts, define spending on education and health care as consumption expenditures, whereas theories of human capital development suggest that spending on health and education would better be viewed as investment. The importance of human capital alongside physical and natural capital for economic development puts into question efforts to reduce spending on education and health care to reduce a life-cycle deficit.

\section{Conclusions and Policy Implications}

The developing countries examined here witness a rapid aging of their populations, and at the same time they are also seeing a rapid increase rural-urban migration. The former will necessitate more support for the elderly; the latter undermines traditional intra-family support systems. Provided that the children who move to the cities find productive and remunerative employment they may send money to their aging parents who often remain in the rural areas. But the remittances sent to the parents may not be sufficient to meet the needs of the elderly, and they may not be able to purchase the necessary care they require. Considering these demographic changes, traditional intra-family support structures merit a replacement with more formal support systems.

The economic development of countries-trends in labor markets, productivity, investment and economic growth - determines feasible policy responses to population aging. Addressing population aging in countries with a weak economic development may leave workers, employers and/ or dependents worse off, but this is not necessarily the case in countries that benefit from a strong economic development. Countries that have a growing labor productivity and growing per-capita output have choices. The majority of developed economies, which already have a large share of older persons, and the emerging market economies, which have a rapidly increasing share of older persons, are in this position. The policy responses that they favor in response to population aging will have important implications for their economic development and income distribution. Examining common policy responses from a macroeconomic perspective - which recognizes that consumption is but the flipside of income and that higher saving does not necessarily lead to an increase in investment-raises doubts about their adequacy.

The economic differences between countries put in question the uniform policy recommendations to address population aging, especially as the economic development in most countries creates a much wider space for policy responses. Uniform policy advice is often based on an inadequate economic analysis and hasty generalization-for example about the linkages between population aging and labor shortages, or a shrinking labor force and economic growth - or on a partial understanding of macroeconomic relationships.

Rather than viewing population aging as a challenge to economic prosperity, population aging should be viewed as a process of structural change. Changes in the characteristics of population-be they related to age or location, or to income levels and tastes-will naturally lead to changes in the patterns of consumption. Functioning economies should adjust to the changes in demand, and it would appear unreasonable to devise policies that hinder such adjustments. If countries have a shrinking share of young people, it is natural that goods and services for young people make up a shrinking share of economic output. Likewise, if they have a growing share of older persons, the goods and services for older persons should make up a growing share. In the process of such adjustments, some industries will shrink, but others will flou- 
rish and these adjustments do not need to have any negative net effects on economies. Structural change is sine qua non with economic development, and efforts to stop or manage structural change have always been futile and come at considerable economic costs. If the aging of populations encourages higher consumption expenditures on health care sector, countries would be best advised to examine how they may benefit from the expansion of this sector.

Whereas household economics will view spending on health care as a cost - to individuals, households, workers, employers or governments-a macroeconomic perspective will show that sending on health care is also an income. To say that health care will cost $\mathrm{x}$ per cent of GDP is the same as saying that the health care sector contributes $\mathrm{x}$ per cent of GDP. The heath care sector represents a large and growing business in many countries that makes significant contributions to the overall economic development. Naturally, those who will need to pay the health care bill will need higher revenuesotherwise the system will break down - and they will also be interested in keeping the bill small. But it is one thing to make every effort to prevent an inflation of health care costs-which is due to limited completion and stifling regulations [27]—and another thing to avoid a higher consumption of health care. The former makes sense, the latter does not. The money the public sector will spends on health care is money it can get back through contributions and taxes.

One of the most important ways in which demographic change can affect economic development would be through its effects on labor markets. Compared with many developed countries, unemployment rates are low in many developing countries. However, low unemployment rates there are attributable to a strong economic development, and do not suggest a labor shortage that could be attributed to population aging. Despite population aging, these countries have a growing working-age population and labor force, and they also often have a growing labor force participation rate. Rather than an outright labor shortage, the countries may confront a skill shortage. To address a skills shortage in the short run, companies should be allowed to recruit workers with the necessary skills from the retired labor force or foreign labor forces, but to address it in the medium run, countries will need to step up investment in their own population. Such investment must begin at the earliest stages of the life course, and in aging societies in particular it must also extend to the mature stages of life. Investment in education and health is important for all age groups. The best way for countries to address the challenge of demographic transitions, including the aging of populations, is for countries to promote sustained and sustainable economic development. This will require investment in hu- man and physical capital, a wise use of natural capital, and a productive use of financial resources.

The analysis presented here as well as Herrmann [28] underline important economic differences between countries. However, more in-depth studies are needed to examine the economic challenges of population aging in countries which have a particularly weak economic development; countries which confront population decline; and countries that are net oil-exporters; as well as the least developed countries. While many of the least developed countries have a large and growing youth population for decades to come, they also have a growing old-age population. ${ }^{11}$ One the one hand, the least developed countries have a significant need for social protection, as about 50 per cent of their population continues to live with dollar 1.25 per day or less, and on the other they have very limited ability to finance corresponding protection measures. In the Democratic Republic of Congo real GDP per capita adjusted for purchasing power parities amounts to less than dollar 1 per person and day. Thus, even if all economic resources were equally distributed, the entire population would continue to live in extreme poverty. In low-income countries as a group, real GDP per capita adjusted for purchasing power parities is below dollar 3 per person and day.

To gain a more comprehensive understanding of the overall economic implications of population aging, future studies on population aging would ideally adopt a more holistic approach, where the focus on budgets and accounts is complemented by a focus on the macroeconomic relationships between consumption, saving and investment; the focus on old-age dependents is complemented by a focus on other dependents, including children and the unemployed; and the focus on pensions and health care is complemented by a focus on other social protection measures, including unemployment benefits and social security. Many of the challenges associated with population aging appear less daunting if viewed in this broader context of economic relationships, demographic developments, and social protection measures throughout the life course.

\section{REFERENCES}

[1] V. Skirbekk, "Age and Individual Productivity: A Literature Survey,” Max Planck Institute for Demographic Research, MPIDR Working Paper 2003-028. See also: V. Skirbekka, E. Loichinger and D. Weber, "National Stereotypes of Older People's Competence Are Related to Older Adults' Participation in Paid and Volunteer Work”, The Journals of Gerontology, Series B, Psychological Sciences and Social Sciences, Vol. 68, No. 6, 2013, pp. 974-983.

\footnotetext{
$\overline{{ }^{11} \text { For a recent exploratory study on demographic change in low-income }}$ countries, see EWC [29].
} 
[2] R. Fernández-Ballesteros, et al. "Productivity in Old Age," Research on Aging, Vol. 33, No. 2, 2011, pp. 205-226. http://dx.doi.org/10.1177/0164027510395398

[3] G. Burtless, "The Impact of Population Aging and Delayed Retirement on Workforce Productivity," Center for Retirement Research at Boston College, Working Paper 2013-11, Chestnut Hill.

[4] A. Bonilla García and J. V. Gruat, "Social Protection: A Life Cycle Continuum Investment for Social Justice, Poverty Reduction and Sustainable Development," Version 1.0, ILO, Geneva, 2003.

[5] ILO, "Social Protection Floor for a Fair and Inclusive Globalization,” Geneva, 2011.

[6] ILO, "Recommendation Concerning National Floors of Social Protection,” Adoption: Geneva, 101st ILC Session, 14 June 2012

[7] D. E. Bloom, D. Canning and G. Fink, "The Graying of Global Population and its Macroeconomic Consequences," The WDO-HSG Discussion Paper Series on Demographic Issues, No. 2010/4, University of St. Gallen, St. Gallen.

[8] W. A. Lewis, "Economic Development with Unlimited Supplies of Labor,” The Manchester School, Vol. 22, No. 2, 1954, pp. 139-191. http://dx.doi.org/10.1111/j.1467-9957.1954.tb00021.x

[9] J. Fei and G. Ranis, "Development of the Labor Surplus Economy,” Irwin, Homewood, 1964.

[10] M. Herrmann and H. A. Khan, "Rapid Urbanization, Employment Crises and Poverty in African LDCs," Paper Prepared for UNU-WIDER Project Workshop "Beyond the Tipping Point: African Development in an Urban World”, 26-28 June 2008, Cape Town.

[11] UNFPA, "Population Dynamics in the LDCs: Challenges and Opportunities for Development and Poverty Reduction,” New York, 2011.

[12] ILO, Growth, Employment and Decent Work in the Least Developed Countries, Geneva, 2011.

[13] OECD, "Ageing Populations: High Time for Action," Background Paper Prepared for Meeting of G8 Employment and Labour Ministers, 10-11 March 2005, London.

[14] R. Lee, and A. Mason (Eds.) "Population Ageing and the Generational Economy,” Edward Elgar, London, 2010.

[15] D. E. Bloom, D. Canning and G. Fink. "Implications of Population Aging for Economic Growth," Oxford Review of Economic Policy, Vol. 26, No. 4, 2010, pp. 583-612. http://dx.doi.org/10.1093/oxrep/grq038

[16] McKinsey Global Institute, "The Coming Demographic Deficit: How Aging Populations Will Reduce Global Savings," Washington DC, 2005.

[17] D. W. Elmendorf and L. M. Sheiner, "Should America Save Should America Save for Its Old Age? Fiscal Policy, Population Aging and National Saving," The Journal of Economic Perspectives, Vol. 14, No. 3, 2000, pp. 57-74.

[18] S. Dullien, "Central Banking, Financial Institutions and Credit Creation in Developing Countries”, UNCTAD Discussion Paper 2009, No. 193, Geneva.

[19] Trade and Development Report 2008: Commodity Prices, Capital Flows and the Financing of Investment, Geneva and New York, 2008.

[20] UNCTAD, The Least Developed Countries Report 2006: Developing Productive Capacities, Geneva, 2006.

[21] M. Herrmann, "Reflections on Globalization, in Global Youth Action Network (ed.): 'Debating Globalization: International Perspectives on the Global Economic and Social Order', , Brussels, 2007.

[22] IMF, "World Economic Outlook 2007: Globalization and Inequality,” Washington DC, 2007.

[23] IMF and ILO, "The Challenges of Growth, Employment and Social Cohesion," Discussion Document, Joint ILO-IMF Conference in Cooperation with the Office of the Prime Minister of Norway, Oslo, 13 September 2010.

[24] ILO, "World of Work Report 2008: Income Inequality in the Age of Financial Globalization," Geneva, 2008.

[25] UNCTAD, "Trade and Development Report 2012: Policies for Inclusive and Balanced Growth,” Geneva and New York, 2012.

[26] ILO, "Global Wage Report 2012/13: Wages and Equitable growth,” Geneva, 2013.

[27] United Nations, "World Economic and Social Survey 2007: Development in an Ageing World," New York, 2007.

[28] M. Herrmann, "Population Aging and Economic Development: Anxieties and Policy Responses," The Journal of Population Aging, Vol. 5, No. 1, 2012, pp. 23-46.

[29] EWC, "Lower-Income Countries and the Demographic Dividend,” NTA Bulletin No. 5, Honolulu, 2012. 